\title{
PROPORSI ANGGARAN PROGRAM PERBAIKAN GIZI DI TINGKAT KABUPATEN/KOTA DALAM TAHUN 2003-2005
}

\author{
Siti Sundari ${ }^{1}$ \\ ${ }^{1}$ Peneliti di Puslitbang Sistem dan Kebijakan Kesehatan
}

\section{ABSTRACT
PROPORTION OF DISTRICT ALLOCATED BUDGET FOR NUTRITION IMPROVEMENT PROGRAM IN 2003-2005

The 2004 Indonesian Households survey indicated that Nutritional status of the Indonesian's underfives had not shown positive improvement since 2000 -2005. Factors influence that conditions among others, were less funds allocated for nutrition programs, lack of coordination between sectors and within programs and lack of personnel motivation to enhance nutrition services.

This study using cross-sectional design was carried out at 6 Districts during the year 2006 and aims to analise the proportion of $\mathrm{DHO}$ allocated for Nutrition improvement program during the year 2003-2005. The data was analysed descriptively using Excell program.

The results showed that the proportion of Nutrition Program Budget was relatively equal every year, with the exception of higher proportion in 2003 and was second highest compare to other DHO program's budget. The type of activities carried out were relatively similar every year including the distribution of meals to Posyandu and schools. There were some contribution made by other units within the DHO to improve nutrional status of the underfives. The success of nutrition services was not achieved without close coordination and support from other sectors, therefore it is important to prioritize activities and budget allocation within the related programs

Keywords: nutrition program, budget, district

\section{PENDAHULUAN}

$\mathrm{H}$ asil Survei Kesehatan Rumah Tangga tahun 2004 menunjukkan bahwa status gizi balita di Indonesia sejak tahun 2000 - 2005 tidak menunjukkan adanya perubahan ke arah yang lebih baik. Angka prevalensi gizi kurang (BB/U) tingkat nasional adalah sebesar 19 persen, prevalensi gizi buruk 3 persen dan prevalensi WUS dengan risiko KEK sebesar 20 persen. Prevalensi gizi kurang tertinggi $(21 \%)$ ditemukan pada anak usia sekolah dasar sedangkan prevalensi gizi lebih sebesar 8 persen ditemukan pada anak usia sekolah dan remaja usia 5-17 tahun ${ }^{(1)}$.

Kemiskinan dan kekurangan gizi merupakan dua sisi yang saling terkait ${ }^{2}$ makin kurang gizi seseorang makin tinggi kemungkinan orang itu akan menderita penyakit yang berakibat meningkatnya kebutuhan biaya untuk pengobatan. Dengan demikian mereka yang hidupnya tidak berkecukupan akan kekurangan modal untuk kegiatan yang bersifat produktif dan akibatnya mereka yang hidupnya hanya dengan biaya terbatas akan menjadi miskin dan yang sudah miskin akan menjadi sangat miskin. Kondisi ini secara makro berpengaruh pada kualitas dan keadaan ekonomi masyarakat, bangsa dan negara.

Guna mengatasi permasalahan kekurangan gizi dan mencegah terpuruknya kualitas dan ekonomi masyarakat, Pembangunan Kesehatan Indonesia diarahkan untuk mencapai Indonesia Sehat 2010 melalui upaya promotif, preventif yang 
dipadukan seimbang dengan upaya kuratif dan rehabilitatif bagi penduduk miskin, daerah tertinggal, daerah bencana, dan kesetaraan jender ${ }^{(3)}$

Secara khusus pelayanan kesehatan bagi masyarakat miskin diarahkan pada upaya perbaikan gizi dan penanggulangan penyakit yang terkait dengan kondisi gizi masyarakat seperti TB paru, malaria dan kesehatan reproduksi Sedangkan program perbaikan gizi masyarakat diprioritaskan pada upaya peningkatan pendidikan gizi, penanggulangan kekurangan energi dan protein, penanggulangan anemia gizi besi, GAKY, kekurangan vitamin A dan kekurangan zat gizi mikro. Selain itu dilakukan juga upaya penanggulangan gizi lebih dan pemberdayaan masyarakat untuk pencapaian Keluarga Sadar Gizi.

Dalam implementasi program perbaikan gizi masih ditemukan beberapa permasalahan dan kendala seperti rendahnya anggaran yang dialokasikan untuk program, lemahnya koordinasi lintas program dan lintas sektor sehingga terjadi pendekatan tunggal dalam mengatasi masalah gizi, terfrakmentasinya program program terkait; kurangnya motivasi tenaga gizi dan lemahnya pelatihan kader yang berakibat rendahnya kinerja posyandu ${ }^{(4)}$.

Sehubungan dengan hal tersebut studi ini ingin menjawab pertanyaan penelitian sebagai berikut:

1. Berapa proporsi anggaran program perbaikan gizi yang dialokasikan dari dana anggaran pembangunan kesehatan di tingkat kabupaten berturutturut dalam kurun waktu 3 tahun?

2. Apakah bentuk dan jenis kegiatan program perbaikan gizi yang dilaksanakan sesuai dengan permasalahan yang ada dan berapa besar cakupan pelayanan gizi yang dihasilkan?

3. Apakah terjadi koordinasi dalam pelaksanaan upaya perbaikan gizi tersebut dan berapa kontribusi anggaran program perbaikan gizi yang disumbangkan oleh program lain di lingkungan kesehatan?

\section{TUJUAN}

Penelitian ini bertujuan untuk menganalisis proporsi anggaran Dinas Kesehatan Kabupaten/ Kota yang terkait/ memberikan kontribusi terbesar untuk upaya perbaikan gizi dan identifikasi bentuk serta jenis kegiatan upaya penanggulangan masalah gizi dan peningkatan status gizi masyarakat yang dilakukan dalam kurun waktu 3 tahun.

Secara khusus analisis anggaran ditujukan pada Program KIA, Program Promosi Kesehatan, Program Pencegahan dan Pemberantasan Penyakit serta Lingkungan, dan Program Perbaikan Gizi sendiri dalam tahun anggaran 2003-2005.

\section{BAHAN DAN CARA}

Penelitian sistem kesehatan ini menggunakan disain potong lintang dan nonintervensi. Studi populasi adalah Dinas Kesehatan Kabupaten/ Kota di Indonesia. Sampel kabupaten dipilih berdasarkan nilai rata-rata Indeks Kemiskinan tahun 2004 ('Human Poverty Indeks'/ HPI) sebesar 27,12 $\pm 7,29 \mathrm{SD}$. Berdasarkan kriteria tersebut terpilih enam kabupaten/ kota sampel yaitu kabupaten Pontianak, kota Singkawang, kabupaten Probolinggo, kota Pamekasan, kabupaten Siak Indrapura dan kota Dumai.

Data yang digunakan dalam studi ini diambil dari data dasar studi Perbandingan ideal anggaran UKM dan UKP tahun anggaran 2003 - 2005 di 6 kabupaten/ kota yang dilakukan pada tahun 2006 ${ }^{(5)}$. Data yang dikumpulkan termasuk data perencanaan tahun 2003 s/d 2005 (DASK Kabupaten dan Rumah Sakit, DAK, DAU), profil/ laporan kabupaten dan RS tahun 2003 - 2005 serta peraturan, kebijakan dan petunjuk teknis serta data demografi.

Data awal diolah dan dianalisis menggunakan metode statistik deskriptif dengan program Excell. Analisis anggaran program Dinkes dikategorikan menurut 4 jenis program yang terkait/ memberikan kontribusi terbesar untuk upaya perbaikan 
gizi. Berdasarkan proporsi tersebut dianalisis bentuk dan jenis kegiatan yang dilakukan terkait dengan upaya penanggulangan masalah gizi dan peningkatan status gizi masyarakat termasuk analisis proporsi anggaran menurut Standar Pelayanan Minimal (SPM).

\section{HASIL}

Gambaran Umum Lokasi Penelitian

Data Fasilitas/ Sarana Kesehatan di lokasi penelitian tahun 2005 dapat dilihat pada Tabel 1 di bawah ini.

Tabel 1

Data Fasilitas/ Sarana Kesehatan Tahun 2005

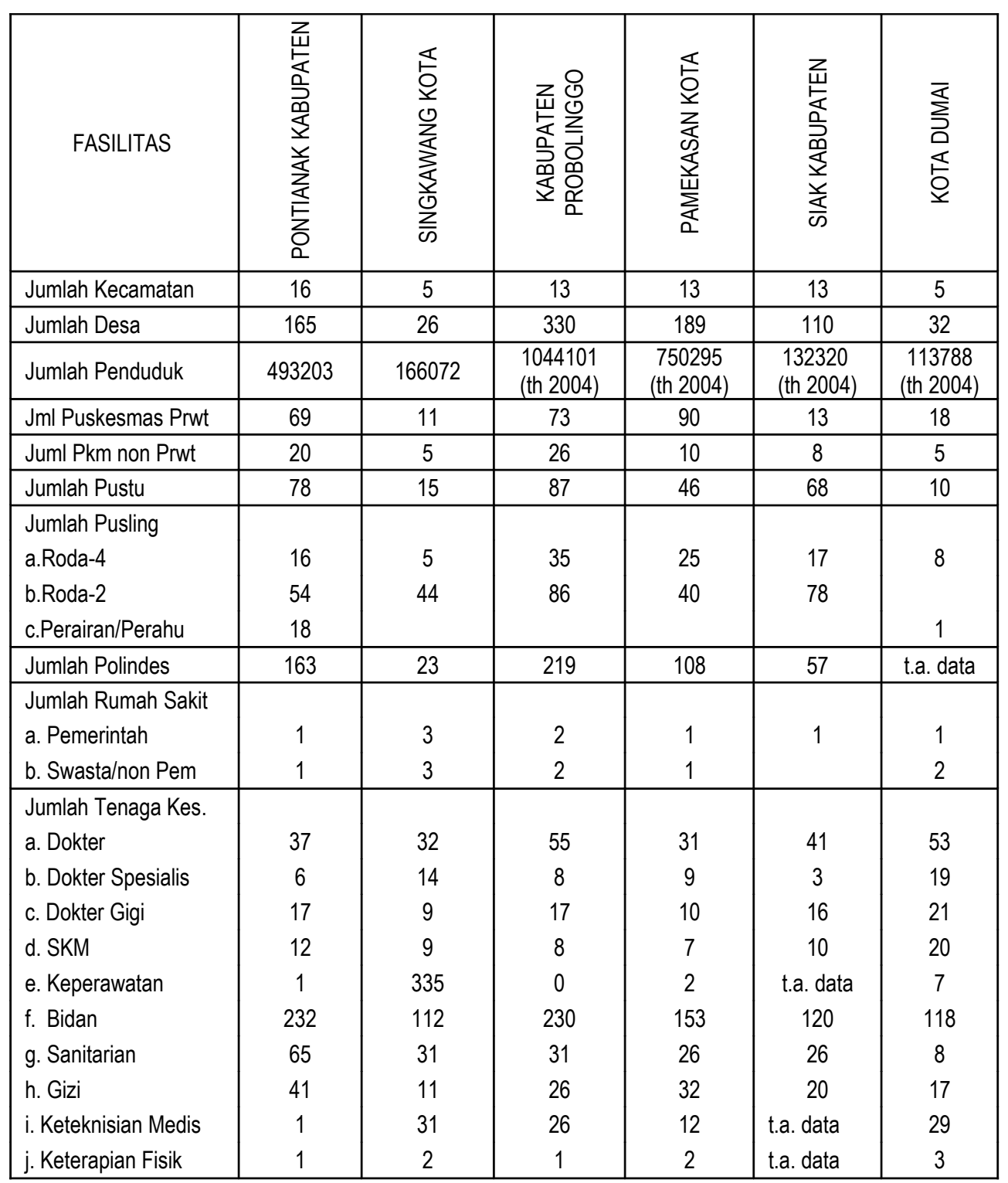


Persentase cakupan pelayanan kesehatan - gizi tahun 2005 di tingkat Kabupaten/ Kota

Tabel 2

Persentase Rata-rata Cakupan Pelayanan Kesehatan-Gizi

di Tingkat Kabupaten/ Kota tahun 2005*

\begin{tabular}{|l|c|}
\hline \multicolumn{1}{|c|}{ Indikator Cakupan Pelayanan tahun 2005 } & $\%$ \\
\hline Cakupan deteksi dini tumbuh kembang balita dan prasekolah & 34.37 \\
\hline Cakupan pemeriksaan kesehatan siswa SD/setingkat oleh nakes atau tenaga terlatih & 54.20 \\
\hline Cakupan pelayanan kesehatan remaja & 28.39 \\
\hline Balita yang Naik Berat badannya (N/D) & 72.48 \\
\hline Balita bawah garis merah (BGM) & 3.16 \\
\hline Desa / kelurahan UCl & 48.09 \\
\hline Cakupan balita mendapatkan kapsul Vit A 2 kali per tahun & 81.15 \\
\hline Cakupan ibu hamil mendapatkan 90 tablet Fe & 77.89 \\
\hline Cakupan pemberian makanan pendamping ASI pada bayi BGM dari keluarga miskin & 73.75 \\
\hline Balita gizi buruk mendapatkan perawatan & 97.50 \\
\hline Desa/ kelurahan mengalami KLB yang ditangani <24 jam & 80.83 \\
\hline Kecamatan bebas rawan gizi & 68.61 \\
\hline Rumah Tangga Sehat & 4.89 \\
\hline Bayi yang mendapat ASI ekslusif & 40.91 \\
\hline Desa dengan garam beryodium baik & 39.29 \\
\hline Posyandu Purnama dan Mandiri & 21.83 \\
\hline * rata-rata cakupan 6 kabupaten sampel & \\
\hline
\end{tabular}

Proporsi anggaran 4 jenis program di Dinkes Kab/Kota tahun 2003-2005

Proporsi anggaran yang dialokasikan untuk Penanggung Jawab kegiatan Gizi, kegiatan Promosi Kesehatan, KIA dan PPPL di tingkat kabupaten/ kota (Gambar 1) menunjukkan trend yang relatif tetap walaupun alokasi dana untuk program gizi terlihat sangat tinggi pada tahun 2003 namun menurun hampir separuhnya pada dua tahun berikutnya. Dana program perbaikan gizi berasal dari berbagai sumber namun terbanyak berasal dari APBD. Dari keempat jenis program pelayanan kesehatan masyarakat tersebut program PPL mendapatkan proporsi dana tertinggi.

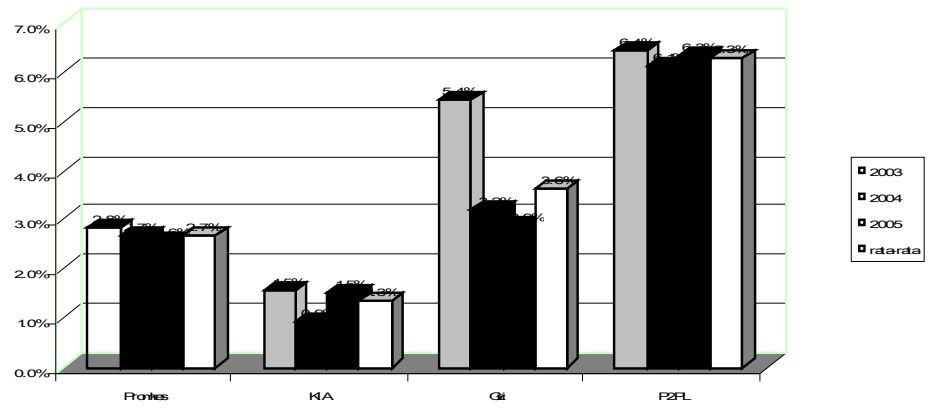


Gambar 1

Proporsi Anggaran 4 Jenis Program Dinas Kesehatan Kabupaten/ Kota Tahun 2003-2005

Bentuk dan jenis kegiatan program perbaikan gizi masyarakat

Dalam kurun waktu 3 tahun Seksi Gizi Kabupaten mengalokasikan anggaran untuk 7 jenis kegiatan seperti terlihat pada Gambar 2 di bawah ini. Proporsi terbesar dialokasikan untuk kegiatan operasional Dinas Kesehatan antara lain berupa kegiatan sosialisasi SPM kesehatan, pertemuan Renkesmas, bimbingan teknis/ monitoring ke puskesmas, puskesmas pembantu dan polindes, pembahasan Gerakan Sayang Ibu (GSI) tingkat kecamatan, evaluasi dan perencanaan pelayanan KIA dan gizi, serta pengolahan data dan informasi/ pemutakhiran data.

Proporsi anggaran terbesar kedua adalah untuk kegiatan perbaikan gizi masyarakat. Proporsi ini menunjukan trend yang meningkat sejak tahun 2003. Jenis kegiatan yang dilakukan meliputi antara lain PMT, PMT-AS, promosi ASI eksklusif, distribusi MP-ASI, pemberian obat cacing pada anak sekolah, dan pemberian Fe pada ibu hamil, pelayanan gizi masyarakat (program KIA dan Kesmas).

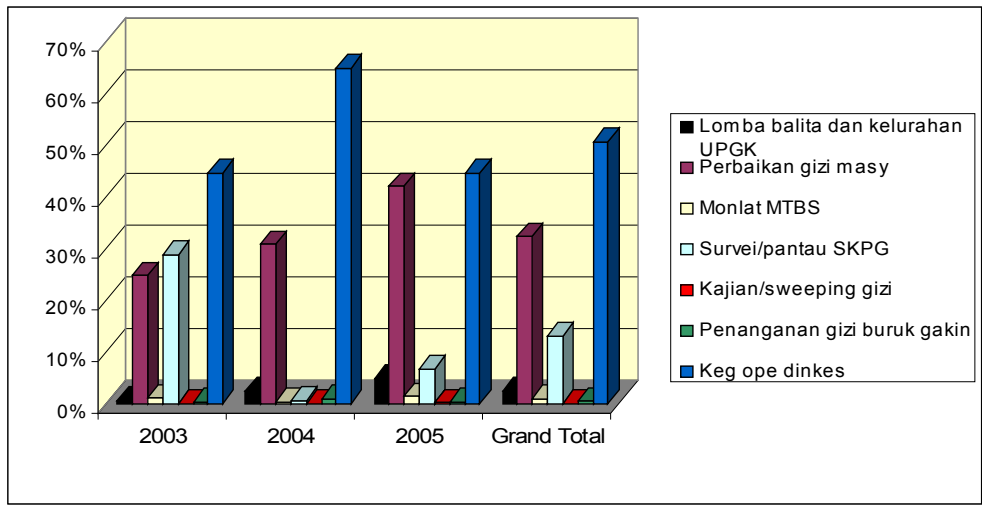

Gambar 2

Proporsi anggaran program gizi menurut jenis kegiatan gizi di tingkat kab/kota dalam tahun 2003-2005

\section{Kontribusi program lain di Dinkes untuk upaya perbaikan gizi}

Kegiatan promosi kesehatan banyak memberikan kontribusi untuk program Perbaikan Gizi melalui upaya Peningkatan Peran Serta Masyarakat, revitalisasi posyandu, lomba sekolah sehat, PHBS, kerjasama LSM, pembinaan UKBM, kampanye kesehatan, Klinik peduli remaja, UKS, UKGS, Kegiatan kesehatan untuk remaja, pelatihan kader dan kampanye kesehatan (Gambar 3).

Kontribusi program PPPL untuk perbaikan gizi dilakukan melalui 2 kelompok besar kegiatan yaitu 1) Penjaringan keluarga rawan gizi yang meliputi surveilans KLB, program pencegahan kecacingan dan 2) Rapat koordinasi lintas program penanggulangan KLB/Gizi buruk (Gambar 4). 


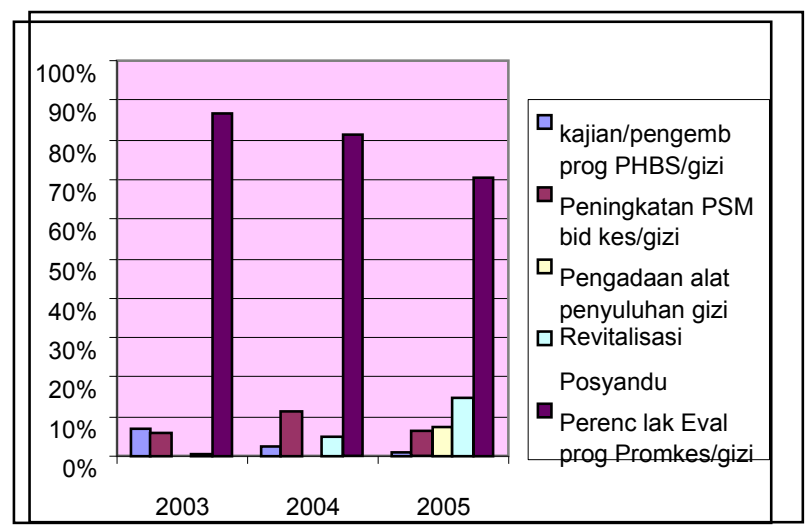

Gambar 3

Proporsi Anggaran Program Promosi Kesehatan Menurut Jenis Kegiatan di Bidang Gizi di Tingkat Kabupaten/ Kota Dalam Tahun 2003-2005

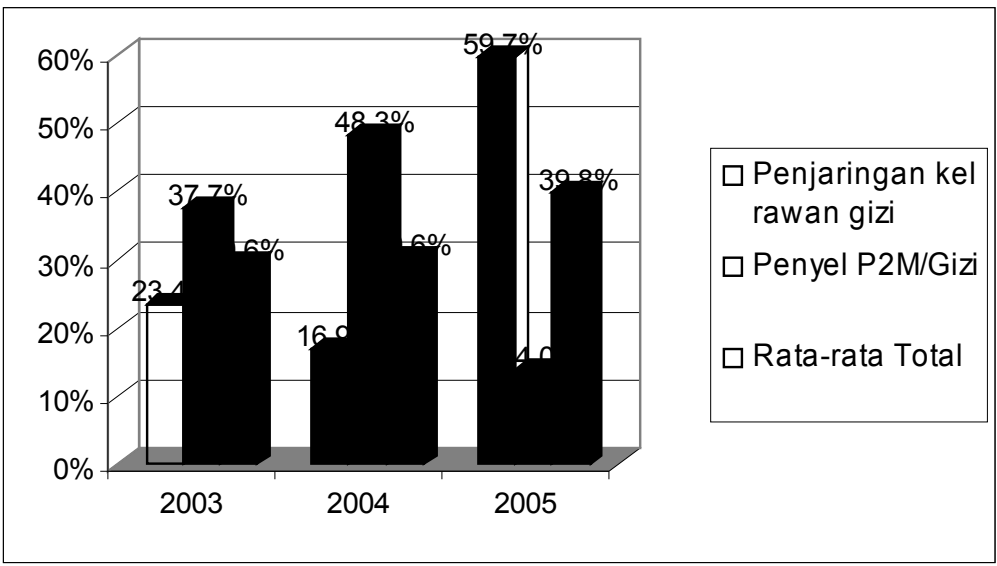

Gambar 4

Proporsi Anggaran Program PPPL menurut Jenis Kegiatan di Bidang Gizi di Tingkat Kabupaten/ Kota Dalam Tahun 2003-2005

Dari sekitar 1,33 persen anggaran Dinas Kesehatan Kabupaten untuk KIA, sebagian kecil dialokasikan untuk kegiatan terkait dengan perbaikan gizi seperti pemberian pelayanan kesehatan anak prasekolah dan usia sekolah dan pelayanan posyandu.

\section{Proporsi anggaran yang dialokasikan} menurut Jenis Pelayanan dan Standar Pelayanan Minimal dalam tahun $2003-2005$
Standar pelayanan minimal (SPM) untuk peningkatan dan perbaikan gizi masyarakat dikelompokkan menurut SPM $1210,1220,1230,2110,2120,2210,2220$, 2230, 2240, 2250, 4120, 6110, 6120, 6130, dan 6140. Berdasarkan acuan tersebut diidentifikasi bahwa ada 3 program yaitu program perbaikan gizi, promosi kesehatan, PPPL dan KIA yang mempunyai kontribusi terbesar untuk pencapaian SPM (Gambar 5). 


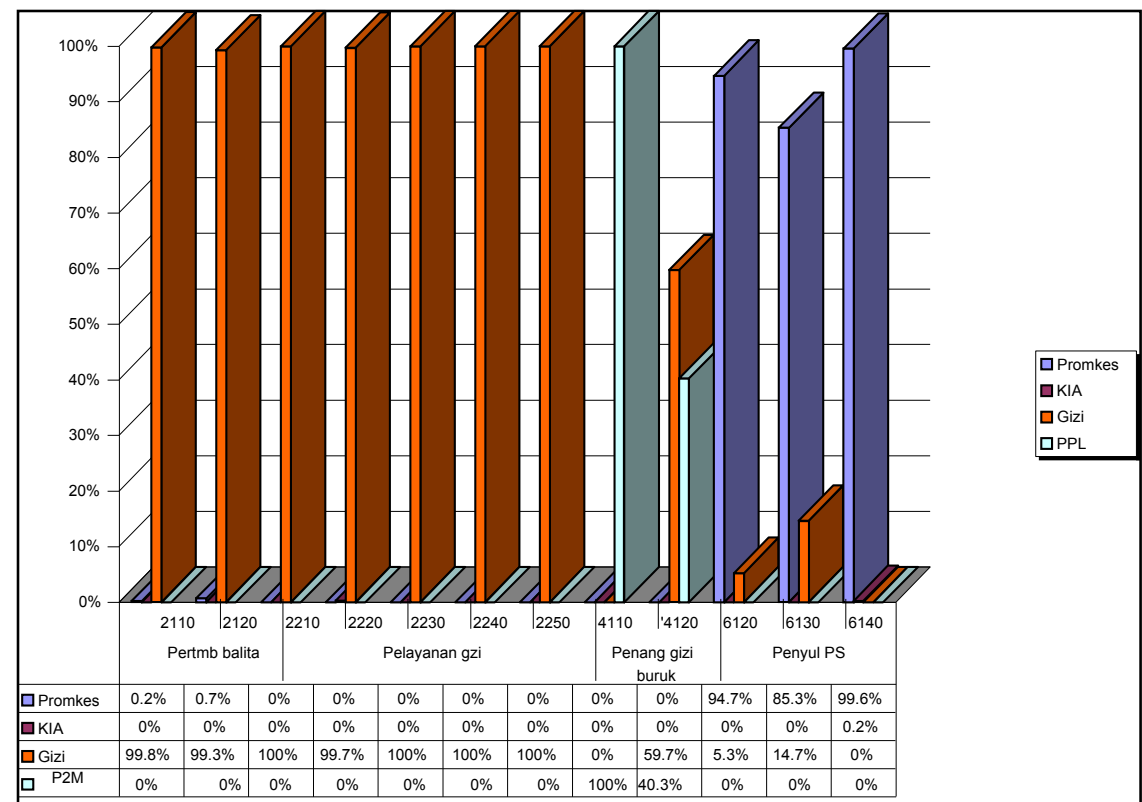

Gambar 5

Proporsi Anggaran Yang Dialokasikan Untuk Mencapai SPM Terkait Dengan Perbaikan Gizi Masyarakat.

\section{BAHASAN}

Rata-rata proporsi anggaran yang dialokasikan untuk program Perbaikan Gizi dibandingkan dengan program lainnya di tingkat kabupaten/kota dalam tahun 20032005 termasuk tinggi namun masih lebih rendah dibanding dengan anggaran PPPL yang mendapatkan proporsi terbesar setiap tahunnya. Program Perbaikan Gizi juga mendapatkan dampak dari dilakukannya kegiatan Promosi Kesehatan seperti upaya Peningkatan Peran Serta Masyarakat, revitalisasi posyandu, lomba sekolah sehat, PHBS, kerjasama LSM, pembinaan UKBM, kampanye kesehatan, Klinik peduli remaja, UKS, UKGS, Kegiatan kesehatan untuk remaja, pelatihan kader dan kampanye kesehatan.

Bila dilihat dari pemenuhan Standar pelayanan minimal (SPM) Program peningkatan dan perbaikan gizi masyarakat merupakan tanggung jawab beberapa program terkait seperti Program KIA, Promosi Kesehatan dan PPPL. Program KIA, walaupun kecil turut memberikan kontribusi dana untuk pencapaian posyandu purnama. Berdasarkan temuan tersebut dapat dikatakan bahwa upaya perbaikan gizi masyarakat sudah dilakukan oleh unit-unit terkait namun masih perlu dipertanyakan apakah koordinasi kegiatan sudah dilaksanakan secara baik dan efisien.

Selain itu pencapaian kecamatan bebas rawan gizi yang merupakan upaya wajib Penyelenggaraan Pemberantasan Penyakit Menular belum sepenuhnya mengalokasikan anggarannya untuk mengatasi permasalahan ini karena tampak bahwa, proporsi anggaran dari Program Gizi untuk mencapai SPM tersebut dialokasikan cukup besar (59.7\%). Sesuai dengan pengelompokan SPM, tanggung jawab Penyuluhan Kesehatan khususnya untuk peningkatan cakupan bayi ekslusif dan desa dengan garam beryodium baik, posyandu purnama adalah tanggung jawab program Promosi Kesehatan dan hal ini terlihat bahwa proporsi anggaran terbesar yang dialokasikan untuk mencapai SPM tersebut berasal dari program Promosi 
Kesehatan. Memperhatikan hal tersebut perlu dikaji apakah terjadi inefisiensi dari anggaran pembangunan dengan adanya penyediaan dana untuk kedua kegiatan tersebut yang disediakan oleh Seksi Gizi.

Dengan adanya berbagai upaya dari tiap program terkait dengan upaya perbaikan gizi masyarakat perlu dikaji apakah anggaran dan kegiatan yang dilakukan sudah mampu mengatasi permasalahan gizi yang ada. Bila ditinjau dari persentase cakupan pelayanan kesehatan - gizi tahun 2005 di tingkat Kabupaten/kota (Tabel 2) tampak bahwa keberhasilan program yang ada untuk mengatasi permasalahan gizi masih sangat rendah hal ini mungkin disebabkan karena kurang terarah dan terkoordinasinya kontribusi anggaran dari tiap program.

Sebagai contoh target program KIA dan gizi adalah sama yaitu kelompok rentan seperti ibu hamil, menyusui, bayi dan balita namun sasaran kelompok rentan ini upayanya berada dalam SPM yang menjadi tanggung jawab Program KIA yang proporsi anggarannya untuk upaya ini cukup kecil. Walaupun upaya mengatasi anemia pada ibu hamil sudah mencapai $77.89 \%$ dari sasaran, namun persentase cakupan bayi dengan ASI eklusif masih rendah. Memperhatikan kondisi ini seyogyanya kedua program dalam menyediakan anggaran dan merencanakan kegiatan bisa saling berkontribusi secara penuh agar output yang dihasilkan bisa lebih optimal.

Program gizi secara khusus sudah mengalokasikan anggaran terkait dengan KIA seperti promosi ASI eksklusif, PMT, pemberian Fe pada ibu hamil, pembahasan kegiatan Gerakan Sayang Ibu (GSI) tingkat kecamatan serta Evaluasi dan Perencanaan Pelayanan KIA dan Gizi. Memperhatikan jenis-jenis program tersebut tampak bahwa kegiatan lebih diarahkan untuk mengatasi permasalahan gizi sesaat seperti program PMT dan belum memperhatikan kegiatan yang lebih bersifat cost effective dan berkesinambungan.

Menurut Soekirman ${ }^{6}$ permasalahan gizi harus dilihat dari outcomenya, yaitu melalui identifikasi masalah dari pola pertumbuhan dan status gizi anak yang dapat dimulai dari
Posyandu. Posyandu perlu dikembalikan lagi kegiatannya sesuai dengan kaidah yang ditetapkan sebelumnya. Posyandu diharapkan mampu melaksanakan pengukuran dan pemantauan status gizi anak serta memberikan penyuluhan pada masyarakat agar masyarakat memantau kondisi gizi dan pertumbuhan berat badan anak, memantau kesehatan masyarakat rentan (apakah anemia, apakah ada tanda-tanda kekurangan yodium). Agar upaya tersebut dapat berhasil dengan baik perlu ada kader, tersedianya fasilitas dan insentif di posyandu.

Pemberian PMT di Posyandu bukan pemberian makanan cuma-cuma sebagaimana saat ini banyak yang memberikan PMT dalam bentuk biscuit karena dana harus dipertanggung jawabkan. Kegiatan PMT seyogyanya dikembalikan lagi sebagai media pendidikan ibu melalui kegiatan pelatihan pemilihan bahan makanan bergizi dan cara penyiapan makanan yang sehat. Upaya pemberdayaan masyarakat khususnya keluarga miskin perlu ditunjang dengan kegiatan peningkatan modal usaha.

\section{KESIMPULAN DAN SARAN}

Keberhasilan cakupan program gizi tidak akan bisa terjadi tanpa adanya keterlibatan dan intervensi langsung dari program lain terkait walaupun kurang diketahui apakah implementasi programprogram tersebut sudah dilaksanakan secara terkoordinasi dan saling melengkapi. Bentuk dan jenis program gizi yang dilakukan hendaknya diprioritaskan pada kegiatan yang menghasilkan dampak terbesar dan tidak hanya pada kegiatan yang mampu mengatasi permasalahan sesaat.

Penyediaan anggaran yang sesuai SPM tampaknya belum secara ekslusif dilakukan oleh tanggung jawab unit yang ditunjuk. Oleh karena itu dalam perencanaan anggaran yang disusun berdasarkan ketentuan SPM mulai dari tingkat pusat sampai dengan daerah, perlu diperhatikan proporsi kebutuhan anggaran tiap program agar tidak terjadi tumpang tindih dan dapat dicegah terjadinya penggunaan anggaran yang 
kurang efisien. Selain itu kemampuan tiap unit untuk melaksanakan SPM perlu ditunjang dengan sumber daya manusia yang kompeten dalam pelaksanaan kegiatannya. Perlu diperhatikan pula apabila anggaran SPM dialokasikan oleh lebih dari satu sumber dana perlu disiapkan mekanisme kerjasama lintas program yang lebih efektif dan efisien.

\section{RUJUKAN}

1. Badan Penelitian dan Pengembangan Kesehatan, 2004. Survei Kesehatan Nasional 2004, SKRT Volume 2: Sudut Pandang Masyarakat, hal: 23-29.

2. Azrul Azwar, 2004. Kecenderungan Masalah Gizi dan Tantangan di Masa Datang. Makalah pada Pertemuan Advokasi Program Perbaikan Gizi Menuju Keluarga Sadar Gizi. Hotel Sahid, Jakarta, 27 September 2004.
3. Supari S.Fadilah, 2005. Pemecahan Masalah Kesehatan Masyarakat di Indonesia. Pertemuan Seruan Aksi Nasional 'Tingkatkan Derajat Kesehatan Masyarakat. Jakarta, 21 November 2005.

4. Taslim, N.A. Kontroversi seputar gizi buruk: Apakah ketidak berhasilan Departemen Kesehatan? Diambil dari http://gizi.net/makalah/index.shtml, tanggal 1 November 2007

5. Siti Sundari, dkk.2007. Perbandingan ideal Anggaran Upaya Kesehatan Masyarakat (UKM) dan Upaya Kesehatan Perorangan (UKP) di Tingkat Kabupaten/Kota. Buletin Penelitian Sistem Kesehatan, No.1(10): 10-15.

6. Soekirman. Perlu Paradigma Baru untuk Menanggulangi Masalah Gizi Makro di Indonesia.Diambil dari http://gizi.net/makalah/index.shtml, tanggal 1 Oktober 2007 